\title{
Pathogenic variability among Pasteurella multocida type A isolates from Brazilian pig farms
}

João Xavier de Oliveira Filho ${ }^{1}$, Marcos Antônio Zanella Morés², Raquel Rebellato², Jalusa Deon Kich²*, Maurício Egidio Cantão², Catia Silene Klein², Roberto Maurício Carvalho Guedes ${ }^{3}$, Arlei Coldebella², David Emílio Santos Neves de Barcellos ${ }^{1}$ and Nelson Morés ${ }^{2}$

\begin{abstract}
Background: Pasteurella multocida type A (PmA) is considered a secondary agent of pneumonia in pigs. The role of PmA as a primary pathogen was investigated by challenging pigs with eight field strains isolated from pneumonia and serositis in six Brazilian states. Eight groups of eight pigs each were intranasally inoculated with different strains of PmA (1.5 mL/nostril of $10 \mathrm{e} 7 \mathrm{CFU} / \mathrm{mL}$ ). The control group $(n=12)$ received sterile PBS. The pigs were euthanized by electrocution and necropsied by $5 \mathrm{dpi}$. Macroscopic lesions were recorded, and swabs and fragments of thoracic and abdominal organs were analyzed by bacteriological and pathological assays. The PmA strains were analyzed for four virulence genes (toxA: toxin; pfhA: adhesion; tbpA and hgbB: iron acquisition) by PCR and sequencing and submitted to multilocus sequence typing (MLST).

Results: The eight PmA strains were classified as follows: five as highly pathogenic (HP) for causing necrotic bronchopneumonia and diffuse fibrinous pleuritis and pericarditis; one as low pathogenic for causing only focal bronchopneumonia; and two as nonpathogenic because they did not cause injury to any pig. PCR for the gene pfhA was positive for all five HP isolates. Sequencing demonstrated that the pfhA region of the HP strains comprised four genes: tpsB1, pfhA1, tpsB2 and pfhA2. The low and nonpathogenic strains did not contain the genes tpsB2 and pfhA2. A deletion of four bases was observed in the pfhA gene in the low pathogenic strain, and an insertion of $37 \mathrm{~kb}$ of phage DNA was observed in the nonpathogenic strains. MLST clustered the HP isolates in one group and the low and nonpathogenic isolates in another. Only the nonpathogenic isolates matched sequence type 10; the other isolates did not match any type available in the MLST database.
\end{abstract}

Conclusions: The hypothesis that some PmA strains are primary pathogens and cause disease in pigs without any co-factor was confirmed. The pfhA region, comprising the genes tpsB1, tpsB2, pfhA1 and pfhA2, is related to the pathogenicity of PmA. The HP strains can cause necrotic bronchopneumonia, fibrinous pleuritis and pericarditis in pigs and can be identified by PCR amplification of the gene pfhA2.

Keywords: Respiratory diseases, Pigs, Bronchopneumonia, Polyserositis, pfhA, MLST

\footnotetext{
* Correspondence: jalusa.kich@embrapa.br

${ }^{2}$ Embrapa Suinos e Aves, P.O. Box 121, Concórdia, Santa Catarina 89700-000,

Brazil

Full list of author information is available at the end of the article
}

(c) The Author(s). 2018 Open Access This article is distributed under the terms of the Creative Commons Attribution 4.0 International License (http://creativecommons.org/licenses/by/4.0/), which permits unrestricted use, distribution, and reproduction in any medium, provided you give appropriate credit to the original author(s) and the source, provide a link to the Creative Commons license, and indicate if changes were made. The Creative Commons Public Domain Dedication waiver (http://creativecommons.org/publicdomain/zero/1.0/) applies to the data made available in this article, unless otherwise stated. 


\section{Background}

Pasteurella multocida capsular type A (P. multocida type A) is one of the most common agents associated with bronchopneumonia in pigs [1]. P. multocida type A is usually considered a secondary agent of enzootic pneumonia originally caused by Mycoplasma hyopneumoniae (M. hyopneumoniae) infection [2, 3]. A few studies have reproduced pneumonia, septicemia or pleurisy in pigs by intranasal or intratracheal challenge, commonly with repeated doses of P. multocida [3-5]. According to Ross [6], the difficulty of reproducing the disease in the absence of infectious or noninfectious cofactors is a major limitation to demonstrating the primary role of $P$. multocida type A in pneumonic lesions in pigs. However, our group has successfully developed a model to reproduce the disease in pigs inoculated with a field strain of P. multocida type A [7]. This model is useful for studying the pathogenicity of other P. multocida type A isolates in the specific pig host.

In this context, Pors et al. [8] previously explored the genetic diversity among isolates of $P$. multocida and its association with pathogenicity. Genetic diversity can be assessed using various DNA-based methods. For P. multocida studies, Subaaharan et al. [9] proposed multi-locus sequence typing (MLST). The toxA, tbp $A, p f h A$ and capsule biosynthesis genes have been suggested as epidemiological markers of virulence-associated genes (VAGs) in P. multocida field strains [10], and therefore, multiplex PCR for the tox $A, t b p A, h g b B$ and $p f h A$ genes was designed for rapid virulence typing [11]. Thus, the objective of the present study was to investigate the capacity of eight $P$. multocida type A field strains to cause disease in healthy pigs.

The P. multocida type A strains were screened by PCR for four virulence genes: tox $A$, a protein Gln-deamidating toxin gene; $p f h A$, a filamentous hemagglutinin gene involved in adhesion; and $t b p A$ and $h g b B$, transferrin-binding protein and hemoglobin-binding protein genes involved in iron acquisition. These genes were further analyzed by sequencing, and the strains were compared by MLST of seven housekeeping genes ( $a d k, \operatorname{aro} A$, deoD, $g d h A, g 6 p D$, $m d h$, and $p g i)$.

\section{Methods}

Animals

Seventy-six 120-day-old pigs each weighing $74 \mathrm{~kg}$ were used in this study. The animals were derived from a herd with high health status raised at the facilities of the Embrapa Swine and Poultry Research Center. This herd was populated with caesarean-derived colostrum-deprived animals in 2009. Every six months, the pigs are screened for the pathogens described in Table 1, and this procedure was repeated four days before inoculation. Furthermore, respiratory diseases such as enzootic pneumonia, influenza, polyserositis (Glässer disease), atrophic rhinitis, pleuropneumonia and pasteurellosis have never been diagnosed in the herd. The herd is protected by strict biosecurity guidelines and has health barriers that include closed rooms with positive pressure and visitor restriction.

\section{Animal housing}

Four days before inoculation, all animals were transferred from the farm to an isolation unit (biosafety level 2). The animals in each group were housed in different rooms (two pigs per pen) with feed and water provided ad libitum. Access to the animals was restricted to the staff. The internal room temperature was monitored daily.

\section{Strains}

Eight strains of $P$. multocida capsular type A from the microorganism collection of the Embrapa Swine and Poultry Research Center were used and are described in Table 2. These strains were isolated from five- to six-month-old pigs with respiratory diseases raised in different herds and were stored in brain-heart infusion

Table 1 Semiannual monitoring of pigs from the high-health-status herd: pathogens and laboratory assays

\begin{tabular}{|c|c|c|c|}
\hline Microorganisms & Samples & Laboratory tests & References \\
\hline \multirow[t]{2}{*}{ Mycoplasma hyopneumoniae } & Tonsillar swabs & Nested PCR & Yamaguti et al. (2008) [43] \\
\hline & Serum & ELISA & Herdcheck ${ }^{\circledast} M$ hyo ELISA - IDEXX \\
\hline \multirow[t]{3}{*}{ Actinobacillus pleuropneumoniae } & Tonsillar and nostril swabs & Bacterial isolation & Quinn et al. (2011) [12] \\
\hline & Tonsillar swabs & PCR & Souza et al. (2008) [44] \\
\hline & Serum & ELISA & APP - ApxIV Ab Test - IDEXX \\
\hline \multirow[t]{2}{*}{ Haemophilus parasuis } & Tonsillar and nostril swabs & Bacterial isolation & Quinn et al. (2011) [12] \\
\hline & Tonsillar swabs & PCR & Redondo et al. (2003) [45] \\
\hline \multirow[t]{2}{*}{ Pasteurella multocida } & Tonsillar and nostril swabs & Bacterial isolation & Quinn et al. (2011) [12] \\
\hline & Tonsillar swabs & PCR & Townsend et al. (2001) [15] \\
\hline PRRS virus & Serum & ELISA & Herdcheck $^{\circledR}$ X3 PRRS ELISA - IDEXX \\
\hline Influenza virus a & Serum & ELISA & Al Multi-Screen Ab test ${ }^{\oplus}$ - IDEXX \\
\hline
\end{tabular}

${ }^{\mathrm{a}}$ Basal levels of circulating antibodies were detected by ELISA. However, genetic material was never detected by RT-PCR 
Table 2 Pasteurella multocida type A isolates used to challenge the pig groups

\begin{tabular}{|c|c|c|c|c|c|}
\hline Strain BRMSA & Group & Brazil State & Brazil Region & Herd production system & Gross lesion \\
\hline 0496 & 1 & Rio Grande do Sul & South & Farrow to finish & Bronchopneumonia \\
\hline 1196 & 2 & Rio Grande do Sul & South & Farrow to finish & Bronchopneumonia \\
\hline 1113 & 3 & Minas Gerais & Southeast & Finisher & Fibrinous pleuritis \\
\hline 1197 & 4 & Rio Grande do Sul & South & Finisher & Bronchopneumonia \\
\hline 1198 & 5 & Santa Catarina & South & Finisher & Bronchopneumonia \\
\hline 1199 & 6 & Paraná & South & Finisher & Necrosuppurative pleuropneumonia \\
\hline 1200 & 7 & Goiás & Midwest & Finisher & Bronchopneumonia \\
\hline 1201 & 8 & Mato Grosso & Midwest & Finisher & Bronchopneumonia \\
\hline
\end{tabular}

broth (BHI; OXOID LTD, Basingstoke, Hampshire, England) with sheep blood (1:1) at $-70{ }^{\circ} \mathrm{C}$ until use.

The strains were phenotypically and genotypically confirmed as $P$. multocida type A. The phenotypic characterization was performed according to Quinn et al. [12], and capsular typing was based on acriflavine [13] and hyaluronidase [14] tests. Additionally, all isolates were submitted to species-specific ( $k m t 1$ gene) multiplex PCR [15] and to capsular typing $\mathrm{A}(h y a \mathrm{D}-h y a \mathrm{C})$ and $\mathrm{D}(d c b \mathrm{~F})$, as described in Table 3.

\section{Inoculum}

The recovery of $P$. multocida type A from the stock was performed by culture on blood agar plates (Blood Agar
Base, BD Difco ${ }^{\mathrm{Tm}}, 5 \%$ sheep's blood) incubated at $37^{\circ} \mathrm{C}$ for 18-24 h. A subculture on trypticase soy agar (TSA) plates (Difco ${ }^{\mathrm{Tm}}$ ) was incubated at $37^{\circ} \mathrm{C}$ for $18-24 \mathrm{~h}$. For challenge, bacterial cultures from the third passage were used. The inoculum was prepared with sterile phosphate-buffered saline (PBS) containing 10e7 colony-forming units (CFU)/ $\mathrm{mL}$. Serial dilutions and subsequent counting on TSA plates confirmed the inoculum concentration.

\section{Study design}

Eight groups (G1-G8) of eight pigs each were challenged with different strains of $P$. multocida type A. The pigs in the challenged groups (G1-G8) received $3.0 \mathrm{~mL}(1.5 \mathrm{~mL} /$ nostril) of the respective inoculum by slow intranasal

Table 3 Target gene information and primers used for Pasteurella multocida type A identification and detection of virulence factors

\begin{tabular}{|c|c|c|c|c|c|c|c|}
\hline Gene & Function & Location Gene & No. Acc. & Primers & $\begin{array}{l}\text { DNA-sequences of } \\
\text { oligonucleotide primers }\left(5^{\prime}-3^{\prime}\right)\end{array}$ & Product Size (bp) & Reference \\
\hline \multirow[t]{2}{*}{ KMT1 } & \multirow[t]{2}{*}{ Species-specific } & $213-232$ & \multirow[t]{2}{*}{ AF016259 } & KMT1 F & ATCCGCTATTTACCCAGTGG & \multirow[t]{2}{*}{460} & \multirow[t]{8}{*}{ Townsend et al. (2001) [15] } \\
\hline & & $669-649$ & & KMT1 R & GCTGTAAACGAACTCGCCAC & & \\
\hline \multirow[t]{2}{*}{ hyaD-hyaC } & \multirow[t]{2}{*}{ Capsular synthesis } & $8846-8863$ & AF067175 & CAPA F & TGCCAAAATCGCAGTCAG & \multirow[t]{2}{*}{1.044} & \\
\hline & & $9890-9873$ & & CAPA R & TTGCCATCATTGTCAGTG & & \\
\hline \multirow[t]{2}{*}{$\mathrm{dcbF}$} & \multirow[t]{2}{*}{ Capsular synthesis } & $3142-3165$ & AF302465. & CAPD F & $\begin{array}{l}\text { TTACAAAAGAAAGACTAGG } \\
\text { AGCCC }\end{array}$ & \multirow[t]{2}{*}{657} & \\
\hline & & $3789-3766$ & & CAPD R & $\begin{array}{l}\text { CATCTACCCACTCAACCAT } \\
\text { ATCAG }\end{array}$ & & \\
\hline \multirow[t]{2}{*}{$\mathrm{fcbD}$} & \multirow[t]{2}{*}{ Capsular synthesis } & $2881-2896$ & AF302467 & CAPF F & AATCGGAGAACGCAGAAATCAG & \multirow[t]{2}{*}{851} & \\
\hline & & $3733-3714$ & & CAPF R & TTCCGCCGTCAATTACTCTG & & \\
\hline \multirow[t]{2}{*}{ pfhA } & \multirow[t]{2}{*}{ Adherence } & $2409-2427$ & AY035342 & PfhA F & AGCTGATCAAGTGGTGAAC & \multirow[t]{2}{*}{275} & \multirow[t]{2}{*}{ Ewers et al. (2006) [10] } \\
\hline & & $2684-2665$ & & PfhA R & TGGTACATTGGTGAATGGTG & & \\
\hline \multirow[t]{2}{*}{ tbpA } & \multirow[t]{2}{*}{ Iron acquisition } & $68-85$ & Pm0337 & TbPA F & $\prod_{\mathrm{GC}} \mathrm{TTG}$ GTT GGA AAC GGT AAA & \multirow[t]{2}{*}{728} & \multirow{2}{*}{$\begin{array}{l}\text { Ewers et al. (2006) [10] } \\
\text { Modified by Atashpaz } \\
\text { et al. (2009) [11] }\end{array}$} \\
\hline & & $487-470$ & & TbPA R & $\begin{array}{l}\text { TAA CGT GTA CGG AAA AGC } \\
\text { CCC }\end{array}$ & & \\
\hline \multirow[t]{2}{*}{ hgbB } & \multirow[t]{2}{*}{ Iron acquisition } & $308-328$ & Pm0337 & $\mathrm{HgbB} \mathrm{F}$ & TCA TTG AGT ACG GCT TGA C & \multirow[t]{2}{*}{499} & \multirow[t]{2}{*}{ Atashpaz et al. (2009) [11] } \\
\hline & & 1096-1077 & & $\operatorname{HgbB~R}$ & CTT ACG TCA GTA ACA CTC G & & \\
\hline \multirow[t]{2}{*}{ toxA } & \multirow[t]{2}{*}{ Toxin } & 1878-1897 & AF240778 & ToxA F & $\begin{array}{l}\text { TTCT TAG ATG AGC GAC AAG } \\
\text { G }\end{array}$ & \multirow[t]{2}{*}{846} & \multirow{2}{*}{$\begin{array}{l}\text { Lichtensteiger et al. (1996) } \\
\text { [46] modified by Atashpaz } \\
\text { et al. (2009) [11] }\end{array}$} \\
\hline & & $2743-2725$ & & ToxA R & GAA TGC CAC ACC TCT ATA G & & \\
\hline
\end{tabular}


dripping in a sitting position. Animals $(n=12)$ in the control group (G0) received $3.0 \mathrm{~mL}$ of sterile PBS $(1.5 \mathrm{~mL} /$ nostril). Each group was housed in a distinct room.

All 76 pigs were clinically evaluated twice a day (0800-0900 $\mathrm{h}$ and 1600-1700 h), starting on the 3rd day before the inoculation and continuing until the fifth day post inoculation $(5 \mathrm{dpi})$. The parameters evaluated were rectal body temperature, dyspnea (with animals lying down) and cough (after five minutes of animal movement during feeding and barn cleaning).

\section{Necropsy}

Pigs were euthanized by electrocution, bled and necropsied at $5 \mathrm{dpi}$. Animals with severe clinical signs were euthanized immediately because of concerns about animal welfare. The lesion features, distribution and severity were recorded at necropsy. The percentage of lung tissue with macroscopic lesions of pneumonia in each lobe was multiplied by each lobe's relative weight [16]. Pleuritis was classified according to the total affected area using the following scores: 1 (1-25\%), 2 (26-50\%), 3 (51-75\%) and 4 (76$100 \%)$. Fragments of the lung, trachea, mediastinal lymph node, heart, pericardial sac, liver, kidney and spleen were preserved in $10 \%$ buffered formaldehyde for histopathology and immunohistochemistry. Fragments of the same organs and fibrinous exudates of the pleura, pericardium, peritoneum and joints, whenever present, were collected aseptically and transported to the laboratory at $2-8{ }^{\circ} \mathrm{C}$ for bacteriological examination.

\section{Histopathology and immunohistochemistry (IHC)}

Histopathological assays were performed using routine procedures for hematoxylin and eosin staining. Representative slides of each type of lesion were submitted to P. multocida type A detection by IHC assay based on the streptavidin-biotin-peroxidase method $\left(\mathrm{LSAB}^{\mathrm{TM}}\right.$ System-HRP kit; Dako Cytomation ${ }^{\mathrm{TM}}$ ) and a hyperimmune polyclonal antibody (anti-P. multocida type A) produced in sheep. Briefly, tissue fragments with a thickness of 3-5 $\mu \mathrm{m}$ were fixed on poly-L-lysine-treated slides, dewaxed and hydrated. Next, the tissues on the slides were subjected to the following steps: antigen retrieval from tissues by microwave irradiation for $5 \mathrm{~min}$ at $700 \mathrm{~W}$, followed by enzymatic digestion with $0.04 \%$ pepsin ( $\mathrm{pH} \mathrm{7.8)}$ for $10 \mathrm{~min}$ at $37{ }^{\circ} \mathrm{C}$; blocking of endogenous peroxidase with $\mathrm{H}_{2} \mathrm{O}_{2}$; incubation of the sections with anti- $P$. multocida type A primary sheep polyclonal antibody at a dilution of 1:500 for $2 \mathrm{~h}$ at $37^{\circ}$ $\mathrm{C}$; incubation with reagents from an LSAB $^{\circ}$ HRP Kit (Dako Cytomation ${ }^{\odot}$ ) for $30 \mathrm{~min}$ at $37{ }^{\circ} \mathrm{C}$; use of 3-amino-9-ethylcarbazole (AEC) for $5 \mathrm{~min}$ at $37{ }^{\circ} \mathrm{C}$; and counterstaining with Mayer's hematoxylin for $1 \mathrm{~min}$. PBS (pH 7.4) was used for washes between each step.
A lung fragment from a pig previously inoculated with P. multocida type A was used as a positive control. A healthy lung fragment was used as a negative control. The results are expressed according to the intensity of the reaction in the lesion, as follows: $(-)$ absence of immunostaining for $P$. multocida type A; $(+)$ mild focal or multifocal areas of staining (up to $25 \%$ of the lesion); (+ $+)$ moderate focal or multifocal areas of staining (26\% to $75 \%$ of the lesion); and $(+++)$ marked diffuse staining (greater than $75 \%$ of the lesion) [17].

To verify the absence of other primary respiratory pathogens, after challenge and necropsy, IHC of porcine circovirus type 2 (PCV2) [18], influenza virus [19] and M. hyopneumoniae was performed in all lung samples [7]. The PCV2 test was also performed in mediastinal lymph nodes.

\section{Pasteurella multocida recovery}

Samples were plated immediately after collection on blood agar and MacConkey agar $\left(\right.$ Difco $\left.^{\mathrm{TM}}\right)$ and incubated at $37{ }^{\circ} \mathrm{C}$ for $24-48 \mathrm{~h}$ under aerobic conditions. A streak of Staphylococcus aureus was added to an additional plate and incubated microaerophilically at $37{ }^{\circ} \mathrm{C}$ for $24-$ $48 \mathrm{~h}$. The biochemical characterization of the isolates was conducted according to Quinn et al. [12].

\section{Virulence gene profiling}

Four virulence-associated genes (VAGs) were assayed by multiplex PCR (Table 3) [11]: toxA (a toxin gene), pfhA (a gene involved in adhesion), $t b p A$ and $h g b B$ (genes involved in iron acquisition). DNA was extracted by boiling. The characterization of the target genes and primers and the related references are listed in Table 3. Amplification products were analyzed by gel electrophoresis on a $1.0 \%$ agarose gel stained with ethidium bromide and photographed under UV light.

To analyze differences in VAGs and to determine MLST gene relationships, DNA sequencing was performed as follows: $1 \mathrm{ng}$ of DNA was enzymatically fragmented, and libraries were prepared using a Nextera XT DNA Library Prep Kit (Illumina, Inc., San Diego, CA, USA) according to the manufacturer's recommendations. Library size was evaluated on an Agilent 2100 Bioanalyzer (Agilent Technologies, Santa Clara, CA, USA) and quantified by qPCR. Paired-end sequencing $(2 \times 250 \mathrm{bp})$ was performed on an Illumina MiSeq (Illumina, Inc., San Diego, CA, USA) at the Functional Genomics Center, ESALQ, University of São Paulo, Piracicaba, SP. Low-quality reads (phred quality score $<25$ and length $<180)$ and adapters were removed using SeqyClean Software (https://github.com/ibest/seqyclean), reads were assembled using Newbler V. 2.9 (ROCHE), and functional annotation was conducted via the RAST Server (http://rast.nmpdr.org/). 


\section{Multi-locus sequence typing}

The genetic relationships of the eight isolates of $P$. multocida were analyzed by sequence alignment of seven housekeeping genes ( $a d k$, aroA, deoD, $g d h A, g 6 p D, m d h$, and $p g i)$ at http://pubmlst.org/pmultocida_multihost. Sequence types and allelic profiles were submitted to the $P$. multocida multi-host MLST database (http://pubmlst.org/pmultocida_multihost/). A neighbor-joining tree was drawn from the concatenated sequences using MEGA 6.0 [20].

\section{Statistics}

The frequency of animals presenting clinical signs, gross lesions and P. multocida type A positive isolation in the groups was analyzed with Fisher's exact test. The group effect on the lung consolidation area (\%) was calculated with a Kruskal-Wallis test, followed by a Wilcoxon test for multiple comparisons of groups. The SAS statistical software package version 9.2 [21] was used.

\section{Results}

All animals were negative for respiratory pathogens (Actinobacillus pleuropneumoniae, Haemophilus parasuis, Bordetella bronchiseptica, M. hyopneumoniae, PCV2 and influenza virus) when screened before and after inoculation.

\section{Clinical signs}

None of the animals presented clinical signs before challenge. Hyperthermia (rectal temperature $\geq 40{ }^{\circ} \mathrm{C}$ ) and dyspnea were most frequently observed (Table 4). Higher prevalence and severity of clinical signs were observed in groups G1, G3 and G7 $(p \leq 0.001)$ than in the other groups, starting at six hours after challenge and persisting until euthanasia. The average rectal temperature \pm standard error for the animals did not differ $(p>0.05)$ among these challenged groups: $40.44{ }^{\circ} \mathrm{C} \pm 0.11$ (G1), $40.42{ }^{\circ} \mathrm{C} \pm$ 0.19 (G3) and $40.29^{\circ} \mathrm{C} \pm 0.16$ (G7), with peaks above $41^{\circ}$ $\mathrm{C}$ in some animals. Some pigs from groups G2, G4 and G5 also showed hyperthermia and dyspnea; however, fewer animals were affected, with average rectal temperatures of $39.79{ }^{\circ} \mathrm{C} \pm 0.20,39.53{ }^{\circ} \mathrm{C} \pm 0.16$ and $39.72{ }^{\circ} \mathrm{C} \pm$ 0.14 , respectively. The average rectal temperatures of groups G0, G6 and G8 remained within normal limits (38.97 ${ }^{\circ} \mathrm{C} \pm 0.06, \quad 39.01{ }^{\circ} \mathrm{C} \pm 0.04$ and $39.01{ }^{\circ} \mathrm{C} \pm 0.05$, respectively) and did not differ $(p>0.05)$.

Coughs were sporadic and of low intensity despite significant differences among the groups $(p>0.05)$. Furthermore, two pigs (one at $1 \mathrm{dpi}$ and the other at $3 \mathrm{dpi}$ ) in G7 had internal otitis, as evidenced by the way the pigs held their heads down. Vomiting was another common clinical sign observed in some pigs of groups G1,

Table 4 Clinical signs (\%) and pathological lesions (\%) in pigs challenged with Pasteurella multocida type A

\begin{tabular}{|c|c|c|c|c|c|c|c|c|c|c|}
\hline \multirow[t]{2}{*}{ Variables } & \multicolumn{9}{|c|}{ Groupst } & \multirow[t]{2}{*}{$p^{*}$} \\
\hline & $\overline{\mathrm{GO}}$ & G1 & G2 & G3 & G4 & G5 & G6 & G7 & G8 & \\
\hline \multicolumn{11}{|l|}{ Clinical signs } \\
\hline Hyperthermia & $0.00^{\mathrm{b}}$ & $100.0^{\mathrm{a}}$ & $62.50^{\mathrm{ab}}$ & $100.0^{\mathrm{a}}$ & $75.00^{\mathrm{ab}}$ & $75.00^{\mathrm{ab}}$ & $12.50^{\mathrm{b}}$ & $100.0^{\mathrm{a}}$ & $25.00^{\mathrm{b}}$ & $<0.0001$ \\
\hline Dyspnea & $0.00^{c}$ & $100.0^{\mathrm{a}}$ & $37.50^{b}$ & $87.50^{\mathrm{ab}}$ & $0.00^{\mathrm{bc}}$ & $25.00^{\mathrm{bc}}$ & $0.00^{\mathrm{bc}}$ & $100.0^{\mathrm{a}}$ & $0.00^{\mathrm{bc}}$ & $<0.0001$ \\
\hline Cough & $16.67^{b}$ & $50.00^{\mathrm{ab}}$ & $37.50^{\mathrm{ab}}$ & $12.50^{\mathrm{b}}$ & $0.00^{\mathrm{b}}$ & $37.50^{\mathrm{ab}}$ & $0.00^{\mathrm{b}}$ & $87.50^{\mathrm{a}}$ & $0.00^{\mathrm{b}}$ & 0.0002 \\
\hline \multicolumn{11}{|l|}{ Macroscopic lesions } \\
\hline Cranioventral lung consolidation** & $0.00^{c}$ & $62.50^{\mathrm{ab}}$ & $37,5,00^{\mathrm{ab}}$ & $87.50^{\mathrm{a}}$ & $12.50^{\mathrm{b}}$ & $0.00^{\mathrm{bc}}$ & $0.00^{\mathrm{bc}}$ & $75.00^{\mathrm{a}}$ & $0.00^{b c}$ & $<0.0001$ \\
\hline Cranioventral lung consolidation (\%)*** & $\begin{array}{l}0.00 \pm \\
0.00^{\mathrm{b}}\end{array}$ & $\begin{array}{l}3.58 \pm \\
1.51^{\mathrm{ab}}\end{array}$ & $\begin{array}{l}2.53 \pm \\
1.43^{\mathrm{ab}}\end{array}$ & $\begin{array}{l}6.26 \pm \\
2.38^{\mathrm{a}}\end{array}$ & $\begin{array}{l}1.30 \pm \\
1.30^{\mathrm{b}}\end{array}$ & $0.00 \pm$ & $\begin{array}{l}0.00 \pm \\
0.00^{\mathrm{b}}\end{array}$ & $\begin{array}{l}5.01 \pm \\
1.58^{\mathrm{a}}\end{array}$ & $\begin{array}{l}0.000 \pm \\
0.00^{\mathrm{b}}\end{array}$ & 0.0004 \\
\hline Necrotic nodules & $0.00^{c}$ & $62.50^{\mathrm{a}}$ & $37.50^{\mathrm{ab}}$ & $75.00^{\mathrm{a}}$ & $0.00^{\mathrm{bc}}$ & $0.00^{\mathrm{bc}}$ & $0.00^{\mathrm{bc}}$ & $37.50^{\mathrm{ab}}$ & $0.00^{\mathrm{bc}}$ & $<0.0001$ \\
\hline Diffuse fibrinous pleuritis & $0.00^{c}$ & $50.00^{\mathrm{ab}}$ & $0.00^{\mathrm{bc}}$ & $75.00^{\mathrm{a}}$ & $0.00^{\mathrm{bc}}$ & $25.00^{\mathrm{abc}}$ & $0.00^{\mathrm{bc}}$ & $50.00^{a b}$ & $0.00^{b c}$ & $<0.0001$ \\
\hline Mild focal fibrinous pleuritis & 0.00 & 0.00 & 0.00 & 0.00 & 0.00 & 12.50 & 0.00 & 12.50 & 0.00 & 0.7074 \\
\hline Diffuse fibrinous pericarditis & $0.00^{c}$ & $25.00^{\mathrm{abc}}$ & $25.00^{\mathrm{abc}}$ & $62.50^{\mathrm{a}}$ & $0.00 b^{c}$ & $25.00^{\mathrm{abc}}$ & $0.00^{\mathrm{bc}}$ & $37.50^{\mathrm{ab}}$ & $0.00^{b c}$ & 0.0029 \\
\hline Fibrinous peritonitis & $0.00^{\mathrm{d}}$ & $62.50^{\mathrm{a}}$ & $12.50^{\mathrm{bcd}}$ & $37.50^{\mathrm{ab}}$ & $25.00^{\mathrm{abc}}$ & $50.00^{\mathrm{ab}}$ & $0.00^{c d}$ & $50.00^{a b}$ & $0.00^{c d}$ & $<0.0001$ \\
\hline \multicolumn{11}{|l|}{ Microscopic lesions } \\
\hline $\begin{array}{l}\text { Fibrinonecrotic suppurative/fibrinonecro- } \\
\text { haemorrhagic pleuropneumonia }\end{array}$ & $0.00^{c}$ & $87.50^{\mathrm{a}}$ & $50.00^{\mathrm{ab}}$ & $87.50^{a}$ & $0.00^{b c}$ & $0.00^{b c}$ & $0.00^{b c}$ & $75.00^{\mathrm{a}}$ & $0.00^{b c}$ & $<0.0001$ \\
\hline Fibrinopurulent pleuropneumonia & 0.00 & 0.00 & 0.00 & 0.00 & 12.50 & 0.00 & 0.00 & 12.50 & 0.00 & 0.7074 \\
\hline Suppurative lymphadenitis & $0.00^{c}$ & $12.50^{\mathrm{bc}}$ & $37.50^{\mathrm{ab}}$ & $75.00^{\mathrm{a}}$ & $12.50^{\mathrm{bc}}$ & $12.50^{\mathrm{bc}}$ & $0.00 b^{c}$ & $37.50^{\mathrm{ab}}$ & $0.00^{b c}$ & 0.0005 \\
\hline
\end{tabular}

Fever: Rectal temperature $\geq 40.0^{\circ} \mathrm{C}$

*Descriptive level of probability by Fisher's exact test; percentages followed by different letters on the same line differ significantly by Fisher's exact test $(p \leq 0.05)$ **Suppurative bronchopneumonia in the histopathology assay

***ung consolidation was measured based on the total percentage of the affected pulmonary area. Descriptive level of Kruskal-Wallis probability; averages followed by different letters differ significantly by the Wilcoxon test $(p \leq 0: 05)$

tG0 with 12 pigs and G1-G8 with eight pigs per group 
G2, G3, G5 and G7 between 1 and 4 dpi. The animals in groups G0 (control), G6 and G8 remained clinically healthy.

\section{Pathology}

Because of animal welfare concerns, 19 pigs with severe respiratory clinical signs were euthanized before $5 \mathrm{dpi}$, as follows: G1 (5/8), G2 (1/8), G3 (6/8), G5 (2/8) and G7 (5/ $8)$. All other pigs were euthanized at $5 \mathrm{dpi}$. The lesions found are described in Table 4. The primary lesions observed according to the frequency and extension were suppurative cranioventral bronchopneumonia, necrosuppurative/necrohemorrhagic fibrinous pleuropneumonia (Fig. 1a), diffuse fibrinous pleuritis (Fig. 1b), fibrinous pericarditis (Fig. 1c), suppurative lymphadenitis and peritonitis (Fig. 1d), which all differed $(p \leq 0.05)$ among the groups.

The average pulmonary consolidation, excluding the necrosuppurative/necrohemorrhagic bronchopneumonial App-like lesion area, was highest in G3 (6.26\%), followed by G7 (5.01\%), G1 (3.58\%), G2 (2.53\%) and G4 (1.30\%). Histologically, the affected areas had suppurative or fibrinosuppurative bronchopneumonia with abundant neutrophils and bacterial colonies in the lumen of the alveoli, bronchi and bronchioles. Necrosuppurative/necrohemorrhagic fibrinous pleuropneumonia was frequent in pigs from groups G1, G2, G3, G4 and G7, characterized by multifocal areas of coagulation necrosis of the lung parenchyma (Fig. 1e) and associated with suppurative inflammatory exudation (Fig. 1f), proteinaceous material, fibrin, neutrophils, bacterial colonies in the alveolar lumen, necrosis of the vessel walls and possibly hemorrhagic multifocal areas. Fewer oat cells were observed surrounding the necrotic areas in some pigs of groups G3, G4 and G7. The visceral pleura and the adjacent interlobular septa were thickened because of the dilation of lymphatic vessels by fibrin, accumulation of degenerate neutrophils and multiple bacterial colonies. Some lymphatics of the interlobular septa and areas of necrosis were distended and obliterated by fibrin thrombi.

Fibrinous pleuritis was frequently observed but varied in severity among the groups $(p<0.0001)$ (Table 4$)$ : $41.94 \%(13 / 31)$ of the occurrences were focal, and $58.06 \%$ (18/31) were diffuse. Focal pleuritis occurred unilaterally and was always adjacent to lesions in the lung parenchyma. For diffuse pleuritis, 33.33\% (6/18) of the occurrences were unilateral, and $66.66 \%(12 / 18)$ were bilateral. Based on the affected area, pleuritis was scored from 1 to 4 , with 1 indicating focal areas of pleuritis and 4 indicating diffuse pleuritis. Diffuse fibrinous pleuritis was observed in pigs from groups G1, G3, G5 and G7, usually associated with fibrinous pericarditis. Of these pigs, one pig each from G1, G2 and G3; three from G5 (with diffuse pleuritis); and another from G5 (with focal pleuritis) had no lung lesions. Histologically, serositis was characterized by thickening of the pleura with accumulation of fibrin, fibroblasts, degenerated neutrophils and multiple bacterial colonies. The pericardial sac was distended by neutrophils and fibrin.

Suppurative lymphadenitis was common except among animals from groups G6 and G8. This lesion was characterized by neutrophils and fibrin and by the distension of the paratrabecular sinus by proteinaceous edema.

Some pigs in groups G1 $(n=3), \mathrm{G} 3(n=4), \mathrm{G} 5(n=1)$ and G7 $(n=1)$ had peritonitis. Microthrombi in the spleen were observed in one pig in G1 and two pigs in G5. Furthermore, in one animal in each indicated group, necrotic hepatitis (G1, G3 and G7), splenic necrosis (G1, G5 and G7), splenic infarction (G5: Fig. 1g) and lymphoplasmacytic nephritis (G0, G2, G4, G5 and G8) were observed. Internal otitis was confirmed by the suppurative exudate in both pigs from G7 with clinical signs of otitis.

In summary, Pasteurella multocida type A strains were classified by pathogenicity scores according to clinical pathological features primarily produced in inoculated animals, as follows: highly pathogenic strains caused persistent clinical signs and severe lesions consisting of necrosuppurative/necrohemorrhagic bronchopneumonia (App-like) and/or diffuse fibrinous pleuritis and/or pericarditis; low pathogenic strains caused mild clinical signs and only focal bronchopneumonia; nonpathogenic strains did not induce clinical signs, and no lesions were observed. The detailed features of the lesions by strain and pig group are presented in Table 5.

\section{Immunohistochemistry}

Marked diffuse staining $(+++)$ of $P$. multocida was detected by IHC in the fibrinosuppurative exudate of the pleura and pericardium, in areas of necrosuppurative bronchopneumonia (Fig. 1h), and in the the cytoplasm of the majority of lymphocytic cells (Fig. 1i) but also free in inflammatory exudates. Mild $(+)$ to moderate $(++)$ multifocal staining was observed in the exudate in the lumen of the bronchi and bronchioles and in the interlobular septa in areas of suppurative bronchopneumonia. Moderate $(++)$ P. multocida staining was observed in the cytoplasm of the macrophages in the necrotic exudate within the crypts of the tonsils and in macrophages and neutrophils of the mediastinal lymph nodes. P. multocida antigen labeling was mild and multifocal $(+)$ in the kidney, liver and spleen macrophages. Moderate and multifocal $(++)$ P. multocida antigen labeling was observed in a septic infarction area in the spleen (Fig. 1j). Additionally, mild (+) staining of $P$. multocida was visualized in the lumen of vessels in the lung, heart, mediastinal lymph nodes and spleen of some pigs.

\section{Recovery of Pasteurella multocida}

The isolation of $P$. multocida type A from tissues differed among groups $(p \leq 0.05$, Table 6$)$, with the highest 

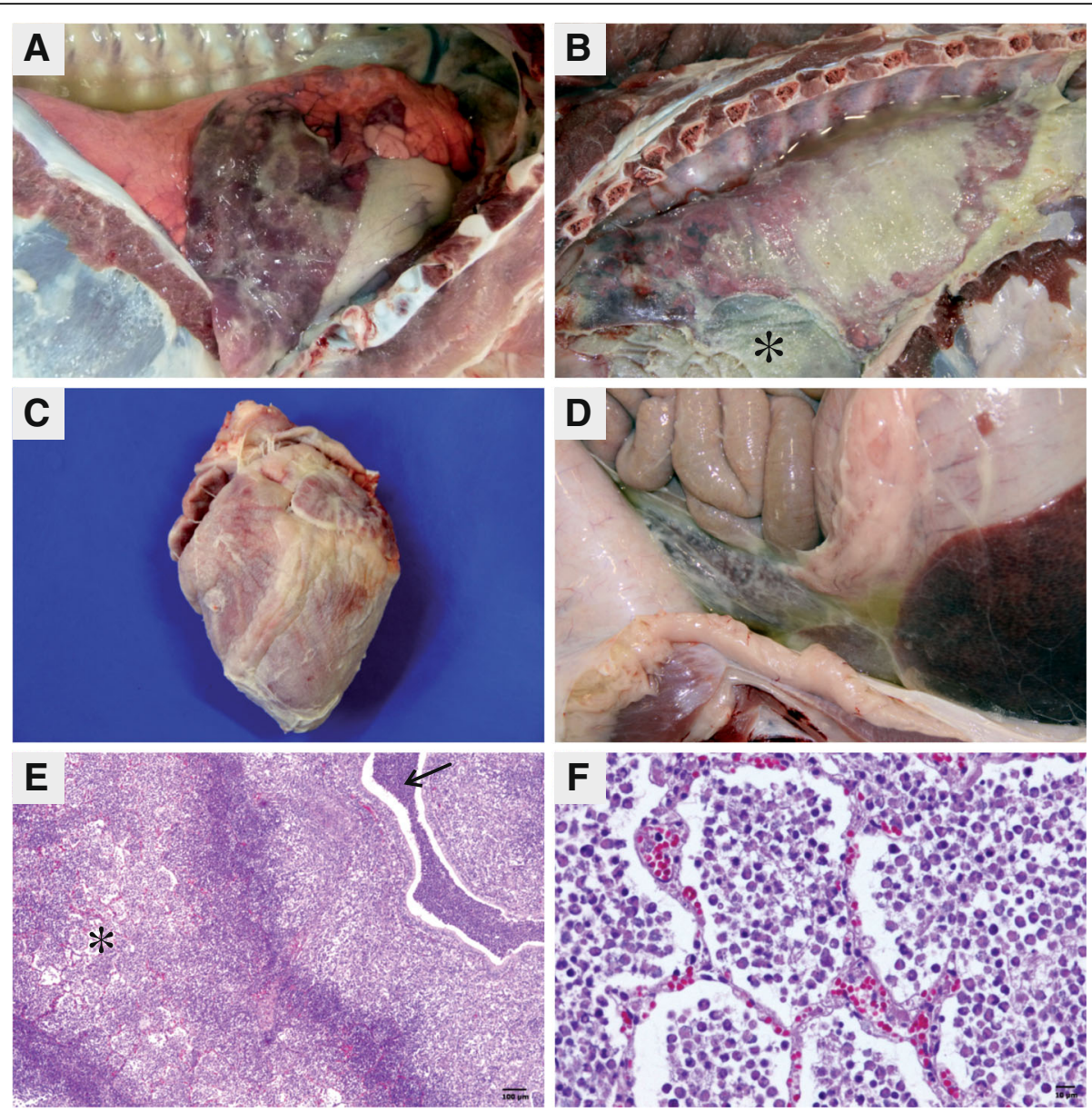

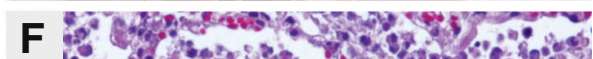

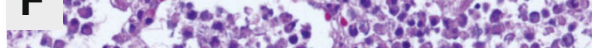

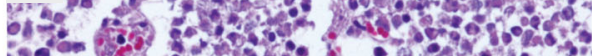

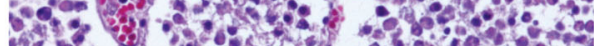

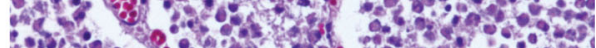

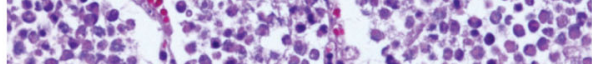
8. 34 .

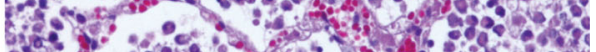

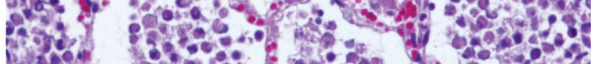

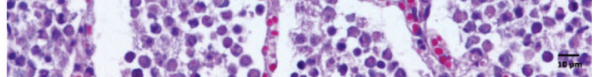
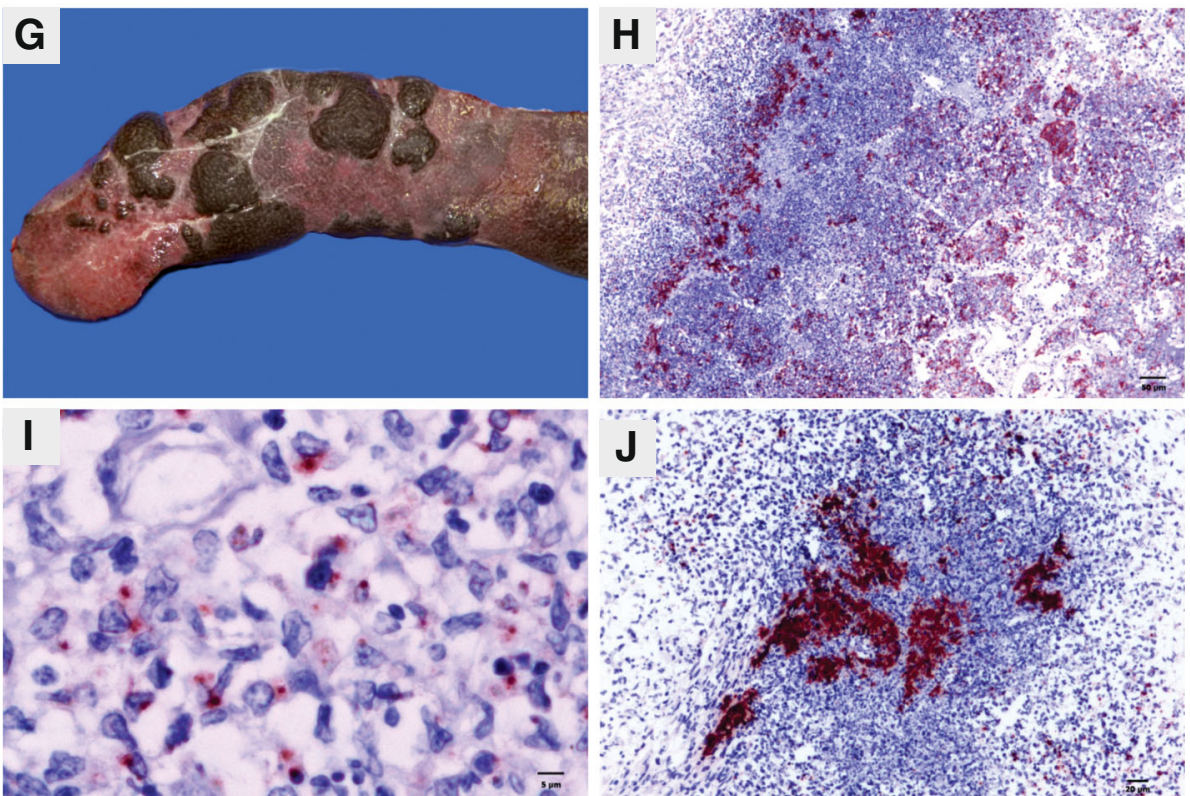

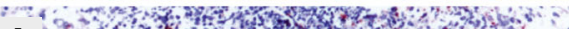

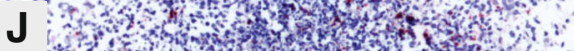

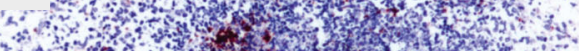
$+2 x$ on

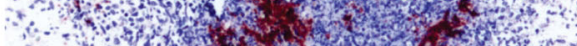
as. $77_{2}+93$
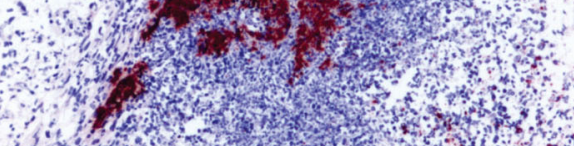

Fig. 1 (See legend on next page.) 
(See figure on previous page.)

Fig. 1 Lesions caused by Pasteurella multocida type A in experimentally challenged pigs. a. Lung, group 2. Focally extensive hemorrhagic pleuropneumonia in the cardiac lobe with fibrin on the pleura. b. Thoracic cavity, group 7. Diffuse fibrinous pleuritis and pericarditis $(*)$. c. Heart, group 3. Diffuse fibrinous pericarditis. d. Abdominal cavity, group 3. Fibrinous peritonitis. e. Lung, group 2. Coagulation necrosis area in the lung parenchyma $(*)$, surrounded by abundant inflammatory cells, mild proliferation of connective tissue and suppurative exudate in the bronchioles (thin arrow). HE. Bar, $100 \mu \mathrm{m}$. f. Lung, group 2. Abundant (+++) inflammatory exudate, predominantly suppurative, intra-alveolar in a coagulation necrosis area on the lung parenchyma. HE. Bar, 10 m. g. Spleen, group 5. Multiple splenic infarcts with fibrin threads on the capsule. h. Lung, group 2. Abundant antigen labeling of $P$. multocida (red labeling) in a coagulation necrosis area in the lung and between degenerated inflammatory cells. Bar, 50 um. i. Lung, group 2. Coagulation necrosis area in the lung with P. multocida antigen labeling (red spots) in the cytoplasm of phagocytic cells. Bar, $5 \mu \mathrm{m}$. j. Spleen, group 5. Moderate (++) antigen labeling of $P$. multocida (red labeling) in a necrotic area. Bar, $20 \mu \mathrm{m}$. Immunohistochemistry, streptavidin-biotin-peroxidase method (LSAB ${ }^{\mathrm{TM}}$ ) with 3-amino-9-ethylcarbazole (AEC) and counterstaining with Mayer's hematoxylin

frequency in pigs from G1 (100\%), G3 (100\%) and G7 (87.5\%). The recovery of $P$. multocida type A from the lung, pericardial sac, pleura, trachea, mediastinal lymph nodes and peritoneum differed among groups $(\mathrm{p} \leq 0.05)$, with the highest recovery in the thoracic cavity from tissue lesions in pigs from G1, G2, G3, G4, G5 and G7. Pasteurella multocida type A was recovered outside the thoracic cavity in 13 pigs. The sites were the peritoneum cavity, liver, spleen and kidney in animals from G1, G3, G5 and G7; the femoral-tibial-tarsal joint in two animals (G5 and G7); and the purulent exudate of the inner ear of two pigs from G7 with clinical signs of otitis. Bacterial growth was not obtained from animals in groups G0, G6 and G8.

\section{Genotypic characterization}

The identity of P. multocida was confirmed by PCR detection of the $k m t$ gene (species- and type-specific) in all tested isolates. Capsular type A was confirmed by detection of the hyaD-hyaC gene in association with a hyaluronidase-positive test and negative acriflavine precipitation. Moreover, the $h g b B$ gene was detected in all eight isolates used in the challenge, and the $\operatorname{tbp} A$ and tox $A$ genes were not detected. The $p f h A$ gene was detected by PCR exclusively in all the high-pathogenicity isolates.

Consequently, the sequence analysis focused on the region of the $p f h A$ gene of all eight isolates. The $p f h A$ region of all five highly pathogenic strains consisted of four genes: tpsB1 (1731 bp); pfhA1 (7842 bp); tpsB2 (1722 bp); and pfhA2 (11,982 bp). The single low pathogenic strain did not have the tpsB2 and pfh $A 2$ genes, in addition to presenting a four-base deletion in the beginning of the pfhA1 gene (at position $892-895 \mathrm{bp}$ ) that caused a frameshift and a premature stop codon. The two nonpathogenic isolates also did not have the tpsB2 and $p f h A 2$ genes and contained a phage DNA insertion of $37 \mathrm{~kb}$ located within the $p f h A 1$ gene (Fig. 2).

MLST profiles and phylogenetic analysis classified the eight isolates into two groups, G1 and G2 (Fig. 3). G1 contained the five highly pathogenic isolates. G2 was composed of the low pathogenic strain (G 2.1) and the nonpathogenic strain (G 2.2). The G1 and G.2.1 isolates did not present a corresponding sequence type (ST) in the MLST database for the seven housekeeping genes analyzed. The isolates of the G.2.2 group showed 100\% similarity to ST 10 .

Table 5 Pasteurella multocida type A strains classification by pathogenicity scores according to clinical pathological features observed in eight challenged pigs per group

\begin{tabular}{|c|c|c|c|c|c|c|}
\hline \multirow[t]{2}{*}{ Strain BRMSA } & \multirow[t]{2}{*}{ Group } & \multirow[t]{2}{*}{ Pathogenic classification } & \multicolumn{3}{|l|}{ Lesions } & \multirow[t]{2}{*}{ Euthanasia ${ }^{b}$} \\
\hline & & & $\mathrm{N}^{\circ}$ of pigs & Area $^{a}$ & Predominant features & \\
\hline 0496 & 1 & High & 8 & 3.58 & $\begin{array}{l}\text { Necrosuppurative/necrohemorrhagic bronchopneumonia } \\
\text { (App-like lesion) with diffuse fibrinous pleuritis }\end{array}$ & 5 \\
\hline 1196 & 2 & High & 4 & 2.53 & $\begin{array}{l}\text { Necrosuppurative/necrohemorrhagic bronchopneumonia } \\
\text { (App-like lesion) with diffuse fibrinous pleuritis }\end{array}$ & 1 \\
\hline 1113 & 3 & High & 8 & 6.26 & $\begin{array}{l}\text { Necrosuppurative/necrohemorrhagic bronchopneumonia } \\
\text { (App-like lesion) with diffuse fibrinous pleuritis and pericarditis }\end{array}$ & 6 \\
\hline 1197 & 4 & Low & 1 & 1.30 & Focal suppurative bronchopneumonia & 0 \\
\hline 1198 & 5 & High & 3 & 0.0 & Diffuse fibrinous pleuritis, pericarditis and peritonitis & 2 \\
\hline 1199 & 6 & Nonpathogenic & 0 & 0.0 & No lesions & 0 \\
\hline 1200 & 7 & High & 7 & 5.01 & $\begin{array}{l}\text { Necrosuppurative/necrohemorrhagic bronchopneumonia } \\
\text { (App like lesion) with diffuse fibrinous pleuritis and pericarditis }\end{array}$ & 7 \\
\hline 1201 & 8 & Nonpathogenic & 0 & 0.0 & No lesions & 0 \\
\hline
\end{tabular}

${ }^{\mathrm{a}}$ Consolidated lung area excluding App-like lesions, $\% ;{ }^{\mathrm{b}}$ Number of pigs euthanized before $5 \mathrm{dpi}$ for animal welfare when severe clinical signs were present 
Table 6 Frequency of P. multocida type A recovery from different organs per group of pigs

\begin{tabular}{|c|c|c|c|c|c|c|c|c|c|c|}
\hline \multirow[t]{2}{*}{ Samples } & \multicolumn{9}{|c|}{ Groups } & \multirow[t]{2}{*}{$p^{a}$} \\
\hline & G0 & G1 & G2 & G3 & G4 & G5 & G6 & G7 & G8 & \\
\hline $\mathrm{N}^{\circ}$ of animals challenged & 12 & 8 & 8 & 8 & 8 & 8 & 8 & 8 & 8 & \\
\hline Whole Animal & $0^{d}$ & $8^{a}$ & $3^{b c}$ & $8^{a}$ & $1^{c d}$ & $3^{\mathrm{bc}}$ & $0^{\text {cd }}$ & $7^{\mathrm{ab}}$ & $0^{\text {cd }}$ & $<0.0001$ \\
\hline Lung & $0^{c}$ & $7^{a}$ & $3^{\mathrm{ab}}$ & $7^{\mathrm{a}}$ & $1^{\mathrm{bc}}$ & $3^{\mathrm{ab}}$ & $0^{\mathrm{bc}}$ & $7^{\mathrm{a}}$ & $0^{\mathrm{bc}}$ & $<0.0001$ \\
\hline Pericardium & $0^{\mathrm{b}}$ & $1^{\mathrm{ab}}$ & $0^{\mathrm{ab}}$ & $4^{\mathrm{a}}$ & $0^{\mathrm{ab}}$ & $2^{\mathrm{ab}}$ & $0^{\mathrm{ab}}$ & $4^{\mathrm{a}}$ & $0^{\mathrm{ab}}$ & 0.0009 \\
\hline Pleura & $0^{d}$ & $5^{a b}$ & $1^{\mathrm{bcd}}$ & $7^{\mathrm{a}}$ & $0^{c d}$ & $2^{\mathrm{bcd}}$ & $0^{\text {cd }}$ & $4^{\mathrm{abc}}$ & $0^{c d}$ & $<0.0001$ \\
\hline Trachea & $0^{b}$ & $3^{\mathrm{a}}$ & $1^{\mathrm{ab}}$ & $4^{a}$ & $1^{\mathrm{ab}}$ & $2^{\mathrm{ab}}$ & $0^{a b}$ & $2^{\mathrm{ab}}$ & $0^{\mathrm{ab}}$ & 0.0383 \\
\hline Mediastinal lymph node & $0^{\mathrm{bc}}$ & $5^{\mathrm{ab}}$ & $2^{b}$ & $8^{a}$ & $0^{\mathrm{b}}$ & $2^{b}$ & $0^{\mathrm{b}}$ & $3^{b}$ & $0^{b}$ & $<0.0001$ \\
\hline Peritoneum & $0^{b}$ & $3^{\mathrm{a}}$ & $0^{\mathrm{ab}}$ & $4^{a}$ & $0^{\mathrm{ab}}$ & $1^{\mathrm{ab}}$ & $0^{a b}$ & $1^{\mathrm{ab}}$ & $0^{\mathrm{ab}}$ & 0.0039 \\
\hline Spleen & 0 & 2 & 0 & 1 & 0 & 1 & 0 & 1 & 0 & 0.3717 \\
\hline Liver & 0 & 2 & 0 & 1 & 0 & 1 & 0 & 1 & 0 & 0.3717 \\
\hline Kidney & 0 & 2 & 0 & 1 & 0 & 2 & 0 & 0 & 0 & 0.1188 \\
\hline Joint & 0 & 0 & 0 & 0 & 0 & 1 & 0 & 1 & 0 & 0.7074 \\
\hline
\end{tabular}

letters on the same line differ significantly by Fisher's exact test $(p \leq 0.05)$

${ }^{a}$ Descriptive level of probability by Fisher's exact test; percentages followed by different

\section{Discussion}

This study successfully demonstrated that some strains of $P$. multocida type A could induce bronchopneumonia, serositis and septicemia in pigs without interference from other pathogens. Furthermore, two strains were categorized as nonpathogenic. Outbreaks of severe respiratory disease in finishing pigs, characterized by fever, dyspnea, serositis and bronchopneumonia, frequently occur in Brazilian pig production herds. Pasteurella multocida type A has been isolated from these outbreaks, associated or not associated with other agents. In some cases, hemorrhagic necrotic foci of pleuropneumonia were found by practitioners in Brazil and named " $A$. pleuropneumoniae-like" because of their similarity to lesions caused by infection with A. pleuropneumoniae. Traditionally, $P$. multocida is regarded as a secondary opportunist in the Porcine Respiratory Disease Complex (PRDC) $[1-3,22]$, and descriptions of cases in which $P$. multocida is suspected to act as a primary agent of lung infection are scarce [4].
Considering the clinical and pathological results obtained with the challenged animals, the isolates were classified into three pathogenic categories: highly pathogenic, low pathogenic and nonpathogenic. The primary observed clinical signs were hyperthermia and dyspnea. Isolates considered nonpathogenic did not primarily induce the disease in healthy pigs; however, these isolates may have an important role in the PRDC $[2,23]$.

Suppurative/fibrinosuppurative bronchopneumonia, necrosuppurative/necrohemorrhagic pleuropneumonia, pleuritis and pericarditis were the primary observed lesions, similar to the results of other studies of pigs challenged with $P$. multocida type A $[4,24]$. In the present study, lung consolidation was not extensive, but P. multocida type A was recovered and visualized in low to moderate amounts in the exudates of the bronchi, bronchiolar lumens and interlobular septa. Therefore, $P$. multocida type $\mathrm{A}$ is likely not the primary agent in extensive consolidations of lung lesions with mixed infection, as observed in the PRDC [23]. The clinical

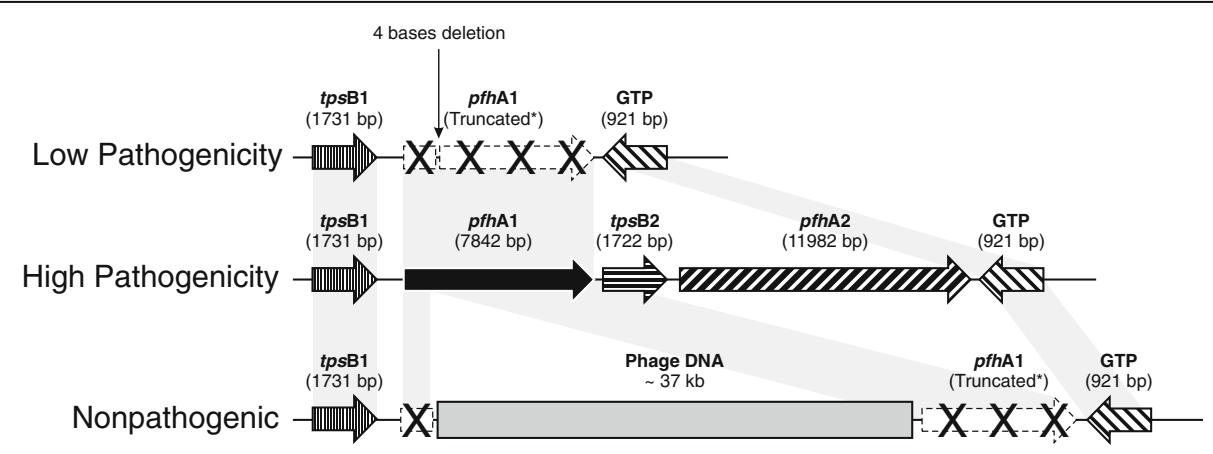

Fig. 2 Schematic representation of the pfhA gene region of P. multocida type A according to pathogenic classification 

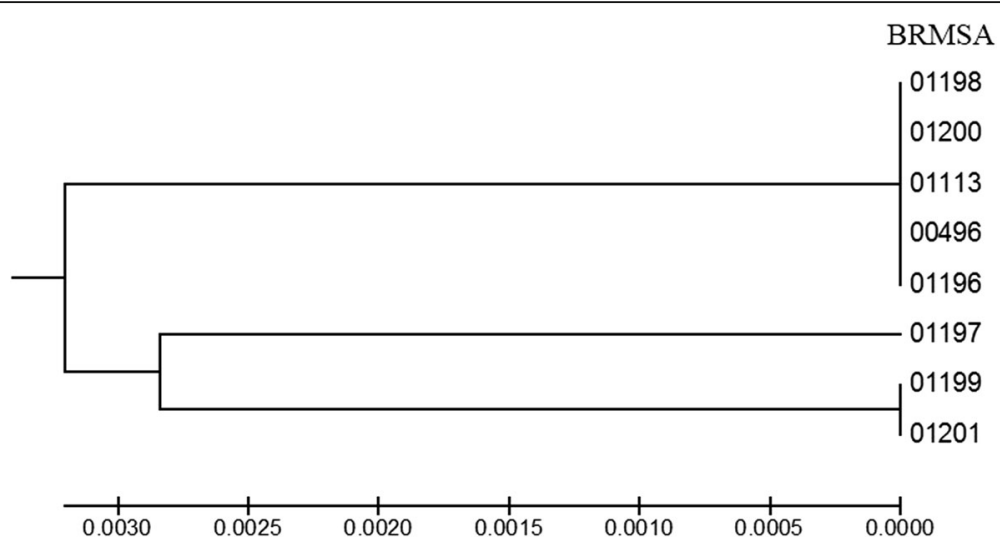

Fig. 3 Dendrogram representative of the 7 concatenated gene sequences used for the MLST of the 8 isolates of P. multocida type A. The MLST was generated by joint analysis of seven housekeeping genes ( $a d k$, aroA, deoD, gdhA, $g 6 p D$, $m d h$, and pgi) using the RIRDC MLST database

pathological picture observed in some challenged groups was similar to that of a cattle disease caused by Mannheimia haemolytica (family Pasteurellaceae) secondary infection triggered by predisposing factors [25].

Some challenged pigs presented peritonitis concurrently with pleuritis and pericarditis, demonstrating bacterial tropism for the serous membranes. Pasteurella multocida type A is frequently associated with pleuritis in slaughtered pigs [26]. In this study, severe and diffuse pleuritis and pericarditis were observed in many challenged groups. These findings are important because they suggest that $P$. multocida type $\mathrm{A}$ is one of the causes of chronic pleuritis and pericarditis observed at slaughter. Additionally, some pigs only presented fibrinous pleuritis, whether associated with fibrinous pericarditis or not, without lung parenchyma injuries. Such lesions are similar to those caused by $H$. parasuis in Glässer disease [27]. Therefore, in clinical cases of bronchopneumonia and serositis, confirmation of the etiological diagnosis with laboratory tests is essential, particularly in the presence of pulmonary necrotic nodules, pleuritis and pericarditis.

P. multocida type A has been commonly isolated as a secondary pathogen from respiratory lesions caused primarily by $M$. hyopneumoniae or influenza A [1-3]. In 2004, Cappuccio et al. [24] described a new form of severe infection by $P$. multocida type A that caused severe fibrinous and necrohemorrhagic lung lesions in pigs on farms in Argentina. Subsequently, a similar disease was observed in Brazil by Embrapa researchers. Necrosuppurative/necrohemorrhagic pleuropneumonia occurred in some challenged pigs with intense $P$. multocida labeling by IHC in these areas. These lesions were called " $A$. pleuropneumoniae-like" or "App-like" lesions due to their similarity to those produced by A. pleuropneumoniae [28]. Notably, as described above, the lesions caused by $P$. multocida type A are similar to those produced by other agents of the family Pasteurellaceae, such as $H$. parasuis, A. pleuropneumoniae and M. haemolytica.

Septicemic forms of $P$. multocida infections have been reported to be characteristic of capsular serotype B, affecting birds, buffalo and pigs [29]. However, septicemic forms with capsular serotype A have also been described in pigs $[4,5,30,31]$. In this study, 13 pigs had a septicemic form. Pasteurella multocida type A was isolated and visualized in several parenchymal organs and in serositis (Table 4). The VAGs associated with the pathogenesis of pneumonia and pleuritis caused by $P$. multocida infection are not clear [32]. The lipopolysaccharide of the bacterial cell wall may have an important role in the induction of the inflammatory response of the host [33]. Additionally, the P. multocida capsule is clearly involved in the evasion of phagocytosis and complement resistance [34]. However, information related to the invasiveness of $P$. multocida is limited. The mechanisms of mucosal resistance to innate immunity and how these mechanisms cause systemic lesions have not been clearly elucidated.

The genetic diversity among $P$. multocida isolates obtained from cases of pneumonia in pigs has been investigated using different molecular techniques [30, $35,36]$. This study demonstrated differences in $p f h A$ PCR results; only highly pathogenic strains were positive. Additionally, the sequence analysis revealed that the PCR target region (pfhA2) was absent in the low pathogenic and nonpathogenic isolates. These results support the importance of the multiplex PCR technique [11] for virulence genes and the $p f h \mathrm{~A} 2$ gene as a possible marker of high pathogenicity.

The sequence of the $p f h \mathrm{~A}$ region of highly pathogenic strains is composed of four genes (tpsB1, PfhA1, tps $\mathrm{B} 2$ and PfhA2). A similar system including two potential virulence $\mathrm{CDs}$ and their accessory genes was previously described by May et al. [37] for the Pm70 strain isolated from fowl cholera. By contrast, as shown in Fig. 2, the 
low and nonpathogenic strains did not have the genes tpsB2 and PfhA2. Additionally, a four-base deletion and a $37 \mathrm{~kb}$ phage DNA insertion in pfhA1 were observed in the low and nonpathogenic strains, respectively.

The $p f h \mathrm{~A}$ gene encodes filamentous hemagglutinin, an adhesin required for bacterial colonization in the upper respiratory system [38]. The PCR results and gene sequencing information demonstrated the absence of $p f h \mathrm{~A} 2$ and a four-base deletion or phage insertion within pfhA1. These findings could help explain the reduction or elimination of pathogenic features. Specifically, for the low pathogenic strain, the inactivation of the $p f h \mathrm{~A} 1$ gene by a premature stop codon did not eliminate pathogenicity; thus, other genes are most likely involved in the pathogenic process. Gene inactivation of $P$. multocida pfhA was previously related to colonization ability in the upper respiratory tract in turkey [39] and mouse [40]. The associated tpsB gene belongs to the TpsB family, which is responsible for transporting sugars (trehalose) to the cell and is therefore related to cellular structure [41].

MLST was previously used to demonstrate clonal differences among $P$. multocida isolates [6, 42]; however, Pors et al. [8] did not find a relationship between MLST results and pulmonary lesions. In this study, MLST differentiated the isolates according to the pathogenic features demonstrated in the experiment. The five highly pathogenic isolates in this analysis originating from 4 different Brazilian states were identical, demonstrating that the highly pathogenic strains are widespread in pig production areas in Brazil. The low pathogenic and nonpathogenic isolates were clustered together in another group with small differences between them. In the MLST analysis, the nonpathogenic isolates were also identical. In addition, only the nonpathogenic isolates were assigned a sequence type (ST10) when submitted to MLST analysis. Of the 17 strains belonging to ST10 deposited in the MLST database, 11 were isolated from pigs, and 8 of these were from pneumonia. By contrast, the high and low pathogenicity isolates were not similar to any strains for the seven housekeeping genes analyzed. These results reinforce our hypothesis that the genetic variability among $P$. multocida type A strains is related to pathogenicity in pigs.

\section{Conclusions}

The hypothesis that some $P$. multocida type A strains are primary pathogens and cause disease in pigs without any co-factor was confirmed. The $p f h \mathrm{~A}$ region, consisting of the genes tpsB1, tpsB2, pfhA1 and pfhA2, is related to the pathogenicity of $P$. multocida type A. The highly pathogenic strains produce necrotic bronchopneumonia, fibrinous pleuritis and pericarditis in pigs and can be identified by PCR of the pfhA2 gene.

\begin{abstract}
Abbreviations
A. pleuropneumoniae: Actinobacillus pleuropneumoniae; AEC: 3-amino-9ethylcarbazole; B. bronchiseptica: Bordetella bronchiseptica; BHI: Brain-heart infusion broth; BRMSA: Brasil Microrganismo Suínos e Aves; CFU: Colonyforming units; dpi: day (s) post inoculation; G1-G8: Experimental groups; $H$. parasuis: Haemophilus parasuis; HP: Highly pathogenic; M.

hyopneumoniae: Mycoplasma hyopneumoniae; MLST: Multilocus sequence typing; PBS: Phosphate-buffered saline; PCR: Polymerase chain reaction; PCV2: Porcine circovirus type 2; PmA: Pasteurella multocida Type A; PRDC: Porcine respiratory disease complex; qPCR: Quantitative PCR; RAST: Rapid Annotation using Subsystem Technology; TSA: Trypticase soy agar; VAGs: Virulence-associated genes
\end{abstract}

\section{Acknowledgments}

The authors are grateful to Dr. Márcia Cristina da Silva (Cedisa) and MSc. Suzana Satomi Kuchiishi (Cedisa) for intellectual support; to Altair Althaus, Dejalmo A. da Silva, Franciele laniski, Franciana A. Volpato (Embrapa), and Kelen Ascoli (Cedisa) for valuable technical support; to Dr. Valéria Dutra (UFMT), Dr. Luciano Nakazato (UFMT), MSc. Eliana Silva Paladino (UFMG) and to veterinarian Lucas Fernando do Santos (MICROVET ${ }^{\oplus}$ ); to others for laboratory support and assistance with sample collection in the states of Mato Grosso, Minas Gerais and Goiás; and to veterinarians Juliana Bassani, Juliana Lazarotto, Lídia Sbaraine Arend, Karine Ludwing Takeuti and Caio C. M. Zaccaro for technical support related to experimental reproduction. RMCG is a recipient of a research fellowship from CNPq.

\section{Funding}

This research was supported by the Brazilian Agricultural Research Corporation (Empresa Brasileira de Pesquisa Agropecuária - Embrapa) \# 06/ 2010; InfoSeg Code 35451, Coordination of Improvement of Higher Education Personnel (CAPES) for a scholarship provided to João Xavier de Oliveira Filho and the National Council for Scientific and Technological Development (CNPq) for a research fellowship to Roberto Mauricio Carvalho Guedes. The funders had no role in study design, or the collection, analysis, interpretation of data and writing the manuscript or the decision to submit the article for publication.

\section{Availability of data and materials}

The eight pfhA regions described in the present study have been deposited in GenBank under the following accession numbers:

BRMSA 1196 (MG023079 - https://www.ncbi.nlm.nih.gov/nuccore/MG023079); BRMSA 0496 (MG023080 - https://www.ncbi.nlm.nih.gov/nuccore/MG023080); BRMSA 1113 (MG023081 - https://www.ncbi.nlm.nih.gov/nuccore/MG023081); BRMSA 1198 (MG023082 - https://www.ncbi.nlm.nih.gov/nuccore/MG023082); BRMSA 1200 (MG023083 - https://www.ncbi.nlm.nih.gov/nuccore/MG023083); BRMSA 1197 (MG023084 - https://www.ncbi.nlm.nih.gov/nuccore/MG023084); BRMSA 1199 (MG023085 - https://www.ncbi.nlm.nih.gov/nuccore/MG023085); BRMSA 1201 (MG023086 - https://www.ncbi.nlm.nih.gov/nuccore/MG023086).

\section{Authors' contributions}

JXOF performed the experiments, analyzed and interpreted the data, wrote the paper, and revised it critically for important intellectual content; MAZM and RR contributed to laboratory assays (microbial and pathological profiles and molecular assays) and drafting of the manuscript, participated in the experimental challenge and necropsy of the animals, and assisted with the analysis and interpretation of data; JDK and DESNB assisted as intellectual advisors of the work and aided in the analysis and interpretation of the data and drafting of the manuscript; MEC performed the MLST and sequencing analyses and drafted the manuscript; CSK participated in the conception, execution and analysis of the bacteriological assays; RMCG provided support and assistance with sample collection of Pasteurella multocida; AC performed the analysis and interpretation of the statistical data; NM was the general supervisor of the research group, participated in the experimental challenge and necropsy of the animals, and assisted in the analysis and interpretation of the data and drafting of the manuscript. All authors have approved the last revised version of the article for submission and have agreed to be accountable for all aspects of the work to ensure that questions related to the accuracy or integrity of any part of the work are appropriately investigated and resolved. 


\section{Ethics approval}

The experiment was conducted at the Embrapa Swine and Poultry Research Center, Concordia-SC, Brazil, in compliance with the Ethical Principles in Animal Experimentation adopted by the National Council for Control of Animal Experimentation (CONCEA) and approved by the Ethics Committee on Animal Experimentation (CEUA/CNPSA) (Protocol \#005/2010). All the experimental procedures were performed strictly in accordance with the approved guidelines and regulations of Institutional Animal Ethics Committee.

\section{Consent for publication}

Not applicable in these sections.

\section{Competing interests}

The authors declare that they have no competing interests.

\section{Publisher's Note}

Springer Nature remains neutral with regard to jurisdictional claims in published maps and institutional affiliations.

\section{Author details}

'Department of Animal Medicine, Universidade Federal do Rio Grande do Sul (UFRGS), Agronomia, Av Bento Gonçalves, 9090, Porto Alegre, Rio Grande do Sul 91540-000, Brazil. ²Embrapa Suinos e Aves, P.O. Box 121, Concórdia, Santa Catarina 89700-000, Brazil. ${ }^{3}$ Preventive Veterinary Medicine Department, Veterinary School, Universidade Federal de Minas Gerais, Belo Horizonte, Brazil.

Received: 4 January 2018 Accepted: 8 August 2018

Published online: 22 August 2018

\section{References}

1. Choi YK, Goyal SM, Joo HS. Retrospective analysis of etiologic agents associated with respiratory diseases in pigs. Can Vet J. 2003:44:735-7.

2. Hansen MS, Pors SE, Jensen HE, Bille-Hansen V, Bisgaard M, Flachs EM, Nielsen OL. An investigation of the pathology and pathogens associated with porcine respiratory disease complex in Denmark. J Comp Pathol. 2010; 143:120-31.

3. Pijoan C, Fuentes M. Severe pleuritis associated with certain strains of Pasteurella multocida in swine. J Am Vet Med Assoc. 1987;191:823-6.

4. Ono M, Okada M, Namimatsu T, Fujii S, Mukai T, Sakano T. Septicaemia and arthritis in pigs experimentally infected with Pasteurella multocida capsular serotype a. J Comp Pathol. 2003:129:251-8.

5. Smith IM, Betts AO, Watt RG, Hayward AHS. Experimental infections with Pasteurella multocida (sero-group a) and an adeno- or enterovirus in gnotobiotic piglets. J Comp Pathol. 1973;83:1-12.

6. Ross RF. Pasteurella multocida and its role in porcine pneumonia. Anim Health Res Rev. 2007;7:13-29.

7. Oliveira Filho JX, Morés MAZ, Rebelatto R, Agnol AMD, Plieski CLA, Klein CS, Barcellos DESN, Morés N. Pasteurella multocida type a as the primary agent of pneumonia and septicaemia in pigs. Pesq Vet Bras. 2015;35:716-24.

8. Pors SE, Hansen MS, Christensen H, Jensen HE, Petersen A, Bisgaard M Genetic diversity and associated pathology of Pasteurella multocida isolated from porcine pneumonia. Vet Microbiol. 2011b;150:354-61.

9. Subaaharan S, Blackall LL, Blackall PJ. Development of a multi-locus sequence typing scheme for avian isolates of Pasteurella multocida. Vet Microbiol. 2010;141:354-61.

10. Ewers C, Lübke-Becker A, Bethe A, Kiebling S, Filter M, Wieler LH. Virulence genotype of Pasteurella multocida strains isolated from different hosts with various disease status. Vet Microbiol. 2006;114:304-17.

11. Atashpaz S, Shayegh J, Hejazi MS. Rapid virulence typing of Pasteurella multocida by multiplex PCR. Res Vet Sci. 2009;87:355-7.

12. Quinn PJ, Markey BK, Leonard FC, Fitzpatrick ES, Fanning S, Hartigen PJ. Pasteurella species, Mannheimia haemolytica and Bibersteinia trehalosi. In: Veterinary microbiology and microbial disease, 27, 2a edition. Ames, lowa: Wiley-BlackwelL; 2011. p. 300-8.

13. Carter GR, Subronto P. Identification of type D strains of Pasteurella multocida with acriflavine. Am J Vet Res. 1973;34:293-4.

14. Carter GR, Rundell DW. Identification of type a strains of Pasteurella multocida using staphylococcal hyaluronidase. Vet Rec. 1975;87:343.
15. Townsend KM, Boyce JD, Chung JY, Frost AJ, Adler B. Genetic organization of Pasteurella multocida cap loci and development of a multiplex capsular PCR typing system. J Clin Microbiol. 2001;39:924-9.

16. Morrison RB, Hilley HD, Leman AD. Comparison of methods for assessing the prevalence and extent of pneumonia in market weight swine. Can Vet J. 1985;26:381-4.

17. Lorenzo CD, Andrade CP, Machado VSL, Bianchi MV, RolimVM CRAS, Driemeier D. Piglet colibacillosis diagnosis based on multiplex polymerase chain reaction and immunohistochemistry of paraffin-embedded tissues. Vet Sci. 2018;19:27-33.

18. Ciacci-Zanella JR, Morés N, Simon NL, Oliveira SR, Gava D. Identification of porcine circovirus type 2 by polymerase chain reaction and mmunohistochemistry on archived porcine tissues since 1988 in Brazil. Cienc Rural. 2006;36:1480-5.

19. Vincent $L L$, Janke $B H$, Paul PS, Halbur PG. A monoclonal-antibody-based immunohistochemical method for the detection of swine influenza virus in formalin-fixed, paraffin-embedded tissues. J Vet Diagn Investig. 1997:9:191-5.

20. Tamura K, Stecher G, Petersonm D, Filipski A, Kumar S. MEGA 6: molecular evolutionary genetics analysis version 60. Mol Biol Evol. 2013;30:2725-9.

21. SAS Institute Inc. SAS/STAT ${ }^{\oplus} 9.2$ User's Guide. Cary: SAS Institute Inc; 2008.

22. Opriessnig T, Giménez-Lirola LG, Halbur PG. Polymicrobial respiratory disease in pigs. Anim Health Res Rev. 2011;12:133-48.

23. Fablet C, Marois-Créhan C, Simon G, Grasland B, Jestin A, Kobisch M, Madec F, Rose N. Infectious agents associated with respiratory diseases in 125 farrow-tofinish pig herds: a cross-sectional study. Vet Microbiol. 2012;157:152-63.

24. Cappuccio J, Leotta GA, Vigo G, Moredo F, Wolcott MJ, Perfumo CJ. Phenotypic characterization of Pasteurella multocida strains isolated from pigs with bronco and pleuropneumonia. In: Blaha T, Pahlitzsch C, editors. Proceedings of the 18th international pig veterinary society congress. Hamburg: International pig veterinary society; 2004. p. 205.

25. López A. Respiratory system. In: McGavin MD, Zachary JF, editors. Pathologic basis of veterinary disease 4a edition. St Louis: Mosby; 2007. p. 463-558.

26. Jirawattanapong P, Stockhofe-Zurwieden N, Leengoed LV, Wisselink H, Raymakers R, Cruijsen T, Peet-Schwering CVD, Nielen M, Nes AV. Pleuritis in slaughter pigs: relations between lung lesions and bacteriology in 10 herds with high pleuritis. Res Vet Sci. 2010;88:11-5.

27. Vahle JL, Haynes JS, Andrews JJ. Experimental reproduction of Haemophilus parasuis infection in swine: clinical, bacteriologic, and morphologic findings. J Vet Diagn Investig. 1995;7:476-80.

28. Frey J. The role of RTX toxins in host specificity of animal pathogenic Pasteurellaceae. Vet Microbiol. 2011;153:51-8.

29. Davies RL, MacCorquodale R, Baillie S, Caffrey B. Characterization and comparison of Pasteurella multocida strains associated with porcine pneumonia and atrophic rhinitis. J Med Microbial. 2003;52:59-67.

30. Pijoan C, Morrison RB, Hilley H. Serotyping of Pasteurella multocida isolated from swine lungs collected at slaughter. J Clin Microbiol. 1983;17:1074-6.

31. Pors SE, Hansen MS, Bisgaard M, Jensen HE. Occurrence and associated lesions of Pasteurella multocida in porcine bronchopneumonia. Vet Microbiol. 2011a;150:160-6.

32. Bethe A, Wieler LH, Selbitz H, Ewers C. Genetic diversity of porcine Pasteurella multocida strains from the respiratory tract of healthy and diseased swine. Vet Microbiol. 2009;139:97-105.

33. Fernandez de Henestrosa AR, Badiola I, Saco M, Perez DE, Rozas AM, Campoy S, Barbe J. Importance of the gale gene on the virulence of Pasteurella multocida. FEMS Microbio Lett. 1997:154:311-6.

34. Harper M, Boyce JD, Adler B. The key surface components of Pasteurella multocida: capsule and lipopolysaccharide. Curr Top Microbiol Immunol. 2012;361:39-51

35. Rubies $\mathrm{X}$, Casal J, Pijoan C. Plasmid and restriction endonuclease patterns in Pasteurella multocida isolated from a swine pyramid. Vet Microbiol. 2002;84:69-78.

36. Zhao G, Pijoan C, Murtaugh MP, Molitor TW. Use of restriction endonuclease analysis and ribotyping to study epidemiology of Pasteurella multocida in closed swine herds. Infect Immun. 1992:60:1401-5.

37. May BJ, Qing Z, Li LL, Paustian ML, Whittam TS, Kapur V. Complete genomic sequence of Pasteurella multocida, Pm70. PNAS. 2001:98:3460-5.

38. Harper M, Boyce JD, Adler B. Pasteurella multocida pathogenesis: 125 years after Pasteur Federation of European Microbiological Societies. FEMS Microbiol Lett. 2006;265:1-10.

39. Tatum FM, Yersin AG, Briggs RE. Construction and virulence of a Pasteurella multocida fhaB2 mutant in turkeys. Microb Pathog. 2005;39:9-17. 
40. Fuller TE, Kennedy MJ, Lowery DE. Identification of Pasteurella multocida virulence genes in a septicemic mouse model using signature-tagged mutagenesis. Microb Pathog. 2000;29:25-38.

41. Chen Q, Haddad GG. Role of trehalose phosphate synthase and trehalose during hypoxia: from flies to mammals. J Exp Biol. 2004;207:3125-9.

42. Hotchkiss EJ, Hodgson JC, Lainson FA, Zadoks RN. Multilocus sequence typing of a global collection of Pasteurella multocida isolates from cattle and other host species demonstrates niche association. BMC Microbiol. 2011;11:115.

43. Yamaguti M, Muller EE, Piffer Al, Kich JD, Klein CS, Kuchiishi SS. Detection of Mycoplasma hyopneumoniae by polymerase chain reaction in swine presenting respiratory problems. Braz J Microbiol. 2008;39:471-47.

44. Souza KK, Klein CS, Kich JD, Coldebella A, Alberton GC. Polymerase chain reaction (PCR) based on the cpx gene for detection of Actinobacillus pleuropneumoniae in natural and experimentally infected pigs. Cienc Rural. 2008;38:1954-60.

45. Redondo VA, Méndez JN, Blanco GD, Boronat NL, Martín CBG, Ferri EFR. Typing of Haemophilus parasuis strain by PCR-RFLP analyses of the tbpA gene. Vet Microbiol. 2003;92:253-62.

46. Lichtensteiger C, Steenbergen SM, Lee RM, Polson DD, Vimr ER. Direct PCR analysis for toxigenic Pasteurella multocida. J Clin Microbiol. 1996;34(12):3035-9.

Ready to submit your research? Choose BMC and benefit from:

- fast, convenient online submission

- thorough peer review by experienced researchers in your field

- rapid publication on acceptance

- support for research data, including large and complex data types

- gold Open Access which fosters wider collaboration and increased citations

- maximum visibility for your research: over $100 \mathrm{M}$ website views per year

At $\mathrm{BMC}$, research is always in progress.

Learn more biomedcentral.com/submissions 